\title{
PENGARUH LINGKUNGAN KERJA DAN KEPUASAN KERJA TERHADAP KINERJA PEGAWAI PADA DINAS SOSIAL KABUPATEN KARANGASEM
}

\author{
A. Nurlaela ${ }^{1}$, Trianasari $^{2}$ \\ 1,2 Jurusan Manajemen, Universitas Pendidikan Ganesha, Singaraja \\ e-mail: apriani613@gmail.com¹, nanatrianasari@undiksha.ac.id²
}

\begin{abstract}
Abstrak
Penelitian ini bertujuan untuk memeroleh temuan eksplanatif yang menguji tentang pengaruh (1) lingkungan kerja terhadap kinerja pegawai secara tidak langsung melalui kepuasan kerja; (2) lingkungan kerja terhadap kepuasan kerja; (3) lingkungan kerja terhadap kinerja pegawai; dan (4) kepuasan kerja terhadap kinerja pegawai pada Dinas Sosial Kabupaten Karangasem. Desain yang digunakan dalam penelitian ini adalah kuantitatif kausal. Subjek yang digunakan dalam penelitian ini adalah seluruh pegawai pada Dinas Sosial Kabupaten Karangasem yang berjumlah 67 orang dan objek penelitian ini lingkungan kerja, kepuasan kerja dan kinerja pegawai. Data penelitian ini dikumpulkan dengan metode kuesioner, kemudian dianalisis menggunakan analisis jalur. Hasil analisis ini secara signifikan menunjukkan bahwa (1) lingkungan kerja berpengaruh terhadap kinerja pegawai secara tidak langsung melalui kepuasan kerja; (2) lingkungan kerja berpengaruh secara positif terhadap kepuasan kerja; (3) lingkungan kerja berpengaruh positif terhadap kinerja pegawai; dan (4) kepuasan kerja berpengaruh positif terhadap kinerja pegawai pada Dinas Sosial Kabupaten Karangasem.
\end{abstract}

Kata kunci : kepuasan kerja, kinerja pegawai, kuantitatif kausal, lingkungan kerja

\begin{abstract}
This study aims to obtain explanative findings that test the effect (1) work environment on employee performance indirectly through job satisfaction; (2) work environment on job satisfaction; (3) work environment on employee performance; and (4) job satisfaction on employee performance at Dinas Sosial Kabupaten Karangasem. The design used in this research is causal quantitative. The subjects used in this study were all 67 employees at Dinas Sosial Kabupaten Karangasem and the object of this research were work environment, job satisfaction and employee performance. The research data were collected using a questionnaire method, then analyzed using path analysis. The results of this analysis significantly indicate that (1) work environment indirectly affects employee performance through job satisfaction; (2) work environment has a positive effect on job satisfaction; (3) work environment has a positive effect on employee performance; and (4) job satisfaction has a positive effect on employee performance at Dinas Sosial Kabupaten Karangasem.
\end{abstract}

Keywords : causal quantitative, employee performance, job satisfaction, work environment

\section{Pendahuluan}

Setiap organisasi baik yang bertujuan memeroleh laba maupun memberikan pelayanan kepada masyarakat menggunakan sumber daya manusia sebagai penggerak kegiatan operasional sehari-hari. Organisasi dalam mencapai suatu tujuan perlu didukung dengan adanya SDM yang memiliki kualitas dan kuantitas yang memadai, karena SDM sebagai penggerak kegiatan. Hal ini dipertegas oleh Sukwiaty (2007) yang menyatakan bahwa sumber daya manusia yang menggerakkan kegiatan operasional baik organisasi yang tujuannya mencari profit maupun nonprofit. Seorang pegawai dituntut untuk memiliki kemampuan dan keterampilan untuk mendapatkan kinerja maksimal. Dengan keterampilan dan kemampuan yang dimiliki oleh pegawai, maka pegawai dapat menyelesaikan pekerjaan dan tanggung jawab yang diberikan dan dibebankan oleh organisasi kepada pegawai. Karena dengan kinerja dapat diketahui seberapa jauh keahlian dan keterampilan pegawai dalam melaksanakan pekerjaan dan tanggung jawab yang diberikan kepadanya. Seorang pegawai nantinya akan merasa nyaman dalam bekerja apabila lingkungan kerjanya baik dan 
nyaman, maka pegawai tersebut akan memiliki tingkat kepuasan kerjanya yang tinggi, karena dengan terciptanya lingkungan kerja yang nyaman maka pegawai bisa terdorong untuk mampu bekerja dengan maksimal sehingga pegawai tersebut akan merasa aman dan nyaman dalam bekerja. Ketika pegawai sudah bekerja dengan baik dan merasa aman dan nyaman maka kinerja yang dihasilkan akan maksimal.

Oleh karena itu, pemberdayaan penggunaan sumber daya manusia menjadi hal yang sangat penting didalam organisasi, karena sumber daya manusia merupakan ujung tobak organisasi yang harus diperhatikan dengan baik. Keberhasilan pemberdayaan sumber daya manusia diukur melalui kinerja pegawai. Hal ini dipertegas oleh Gordon (2002) yang menyatakan bahwa keberhasilan suatu organisasi dapat dicapai dan diukur menggunakan kinerja. Sebuah organisasi tidak akan mendapatkan hasil yang maksimal apabila sumber daya manusia yang dimiliki tidak bekerja secara maksimal. Kinerja pegawai dipengaruhi oleh variabel lingkungan kerja dan kepuasan kerja. Variabel tersebut dipertegas oleh pernyataan Robbins (2003) dan Musriha (2011) yang menyatakan jika lingkungan kerja nyaman dan kepuasan kerja tinggi maka kinerja akan meningkat. Teori tersebut didukung juga dari hasil kajian pengalaman yang dilakukan Sulistiana dan Sarwoko (2014) yang menyimpulkan bahwa variabel lingkungan kerja dan kepuasan kerja berpengaruh positif dan signifikan terhadap kinerja pegawai.

Seiring dengan perkembangan waktu dan persaingan yang semakin ketat, suatu organisasi harus meningkatkan kinerjanya baik dari segi mutu maupun kapasitasnya. Kemampuan pegawai merupakan hal mendasar yang perlu mendapat perhatian baik oleh manajemen swasta maupun kepemerintahan. Oleh karena itu setiap organisasi harus mempersiapkan SDM yang handal dan mampu bersaing dengan organisasi lainnya. Hal tersebut juga berlaku untuk organisasi Dinas Sosial yang berada di Bali. Dinas Sosial merupakan salah satu elemen pemerintahan yang menangani bidang sosial di daerah tertentu. Terdapat beberapa Dinas Sosial yang berada di Bali yaitu Dinas Sosial Kabupaten Karangasem, Dinas Sosial Kabupaten Buleleng, dan Dinas Sosial Kabupaten Bangli. Berdasarkan hasil observasi yang telah dilakukan pada tiga Dinas Sosial tersebut ditemukan fakta mengenai capaian kinerja organisasinya. Dinas Sosial Kabupaten Buleleng dan Dinas Sosial Kabupaten Bangli memiliki capaian kinerja yang lebih besar dibandingkan dengan Dinas Sosial Kabupaten Karangasem. Dilihat dari data kinerja organisasi kedua Dinas tersebut lebih besar dari Dinas Sosial Kabupaten Karangasem. Berdasarkan fakta tersebut maka fokus penelitian dilakukan pada Dinas Sosial Kabupaten Karangasem.

Dinas Sosial Kabupaten Karangasem mempunyai kewajiban untuk membantu Bupati dalam menyelesaikan tugas pemerintahan di bagian sosial yang menjadi wewenangan daerah dan tanggung jawab yang diberikan kepada kabupaten. Dinas Sosial mempunyai tiga bidang pelayanan untuk membantu mensejahterakan kehidupan sosial masyarakat. Bidang pertama yaitu pelayanan dan rehabilitasi sosial yang membantu dalam hal memberikan pelayanan sosial anak terlantar dan lansia, rehabilitasi sosial penyandang disabilitas, dan rehabilitasi sosial tuna sosial. Bagian kedua yaitu perlindungan dan jaminan sosial yang membantu dalam menangani korban bencana, jaminan sosial keluarga, serta pengelolaan statistik dan laporan kesos. Selanjutnya bidang ketiga yaitu pemberdayaan sosial dan penanganan fakir miskin yang membantu dalam hal pemberdayaan sosial perorangan, keluarga dan kelembagaan masyarakat, penanganan fakir miskin, serta kepahlawanan, keperintisan dan kesetiakawanan sosial. Kondisi nyata saat melakukan observasi awal di Dinas Sosial Kabupaten Karangasem dengan jumlah pegawai 67 orang. melalui observasi awal ditemukan bahwa beberapa pegawai masih belum mencapai standar kinerja yang telah ditetapkan oleh Dinas Sosial Kabupaten Karangasem.

Berdasarkan observasi yang telah dilakukan melalui kuesioner awal kepada 10 orang, diketahui 7 pegawai belum mencapai standar kerja. Hal ini menunjukkan kinerja pegawai pada Dinas Sosial Kabupaten Karangasem sebagian besar masih rendah atau belum mencapai standar kinerja. Hal ini perlu mendapatkan perhatian dari pimpinan untuk tetap menjaga kelangsungan organisasi melalui peningkatan kinerja pegawai.

Memberikan kenyamanan pada pegawai sangat penting dalam setiap organisasi. Lingkungan kerja yang aman dan nyaman dapat mendorong pegawai tersebut bekerja lebih semangat dan dapat meningkatkan kinerja pegawai. Salah satu cara yang bisa dilakukan 
organisasi agar dapat memengaruhi kinerja pegawai yaitu dengan memberikan kondisi lingkungan kerja yang baik dan nyaman, karena dengan pemberian lingkungan kerja yang nyaman dapat meningkatkan dan memaksimalkan kinerja pegawai. Salah satu upaya yang dapat dilakukan adalah dengan lingkungan kerja yang memadai, sarana dan prasarana kerja yang lengkap dan sesuai.

Berdasarkan observasi awal ditemukan fakta permasalahan mengenai ruang kerja yang sempit dan kecil, fasilitas kerja yang belum memadai, penataan ruang yang kurang baik menyebabkan penerangan dan sirkulasi atau peredaran udara yang kurang maksimal, kondisi bangunan kurang mendukung, serta hubungan kerja dengan atasan maupun sesama pegawai kurang baik dan harmonis. Hal tersebut menyebabkan pegawai kurang maksimal dalam bekerja, karena lingkungan kerja memiliki peran yang penting dalam mencapai kinerja. Dengan adanya lingkungan kerja yang aman dan nyaman, pegawai dapat bekerja dengan nyaman dan tekun untuk mencapau kinerja yang maksimal. Selain pernasalahan pada lingkungan kerja yang kurang baik dan nyaman, ditemukan juga permasalahan mengenai kepuasan kerja pegawai.

Kepuasan kerja merupakan perilaku umum terhadap seseorang yang memperlihatkan perbedaan dari besar penghargaan yang seharusnya diterima pegawai dengan jumlah yang mereka terima. Keadaan ini sesuai pendapat dari (Handoko, 2001; Sunyoto, 2012) yang menyatakan bahwa kepuasan kerja adalah keadaan emosional seseorang baik yang memuaskan atau tidak memuaskan dengan mana cara para pegawai melihat pekerjaan dan tugas mereka. Apabila pegawai sudah merasa suka dengan tugas dan pekerjaannya hingga pegawai akan bersemangat dan memberikan rasa yang menyenangkan dalam menyelesaikan pekerjaannya. Kondisi nyata pada saat melakukan observasi awal melalui kuesioner awal pada 10 orang pegawai pada Dinas Sosial Kabupaten Karangasem ditemukan 7 pegawai dalam kategori tidak puas dan 3 pegawai dalam kategori puas. Ini menandakan bahwa pegawai pada Dinas Sosial Kabupaten Karangasem belum semua merasa puas terhadap pekerjaannya. Hal ini perlu mendapat perhatian dari pimpinan organsasi, karena dengan adanya rasa puas dalam diri pegawai terhadap pekerjaannya akan menambah semangat pegawai dalam menyelesaikan tugas dan tanggung jawabnya.

Selain itu, permasalahan juga mengenai gaji yang diterima oleh pegawai Dinas Sosial Kabupaten Karangasem belum sesuai dengan Upah Minimun Kabupaten/Kota (UMK) Karangasem Provinsi Bali. Selain fakta permasalahan lingkungan kerja dan kepuasan kerja yang diungkapkan sebelumnya, ditemukan juga fakta permasalahan lain terkait dengan belum tercapainya target kinerja pada Dinas Sosial Kabupaten Karangasem, dimana pihak pimpinan maupun pegawai harus lebih meningkatkan kinerjanya agar target yang direncanakan berjalan sesuai dengan harapan.

Berdasarkan fakta-fakta masalah yang dikemukakan pada Dinas Sosial Kabupaten Karangasem, kinerja pegawai yang rendah diduga disebabkan oleh kondisi lingkungan kerja yang kurang baik dan tidak nyaman, dan kepuasan kerja yang rendah. Fakta-fakta permasalahan ini mengindikasikan bahwa Dinas Sosial Kabupaten Karangasem perlu informasi secara empirik mengenai variabel lingkungan kerja, kepuasan kerja, dan kinerja pegwai serta pengaruh dari variabel lingkungan kerja dan kepuasan kerja terhadap kinerja pegawai secara akurat sebagai bahan atau dasar pertimbangan untuk mengambil keputusan dalam mencegah, memecahkan, memperbaiki masalah dari lingkungan kerja, kepuasan kerja, dan kinerja pegawai yang akan dihadapi oleh pegawai. Padahal pernyataan dari Robbins (2003) dan Musriha (2011) yang mengatakan bahwa jika lingkungan kerja nyaman dan kepuasan kerja tinggi maka kinerja pegawai akan meningkat. Keadaan ini didukung oleh hasil kajian pengamatan dari Sulistiana dan Sarwoko (2014) yang menyimpulkan bahwa variabel lingkungan kerja dan kepuasan kerja berpengaruh positif dan signifikan terhadap kinerja pegawai.

Melihat kesenjangan fakta masalah maka dipandang perlu untuk melakukan penelitian tentang hubungan ketiga variabel tersebut pada Dinas Sosial Kabupaten Karangasem. Berdasarkan latar belakang di atas, dapat pula rumusan masalah yang dapat diajukan pada penelitian ini dirumuskan sebagai berikut: (1) apakah ada pengaruh dari lingkungan kerja terhadap kinerja pegawai secara tidak langsung melalui kepuasan kerja?, (2) apakah ada pengaruh lingkungan kerja terhadap kepuasan kerja? (3) apakah ada pengaruh lingkungan 
kerja terhadap kinerja pegawai?, (4) apakah ada pengaruh kepuasan kerja terhadap kinerja pegawai pada Dinas Sosial Kabupaten Karangasem?

Berdasarkan uraian rumusan masalah dalam penelitian ini, maka tujuan penelitian yang hendak dicapai yaitu untuk menguji pengaruh sebagai berikut: (1) lingkungan kerja terhadap kinerja pegawai secara tidak langsung melalui kepuasan kerja, (2) lingkungan kerja terhadap kepuasan kerja, (3) lingkungan kerja terhadap kinerja pegawai, (4) kepuasan kerja terhadap kinerja pegawai pada Dinas Sosial Kabupaten Karangasem.

Hasil dari penelitian ini diharapkan mampu memberikan dua manfaat, yaitu: (1) manfaat teoritis, dimana hasil dari analisis ini diharapkan nantinya mampu membantu dalam menambah pemahaman serta mengaplikasikannya di bidang manajemen sumber daya manusia yang berkaitan dengan variabel lingkungan kerja, kepuasan kerja, dan kinerja pegawai, (2) manfaat praktis, dimana hasil dari penelitian ini diharapkan nantinya mampu membagikan bantuan ide, pandangan, dan penjelasan serta berguna yang mana berhubungan dengan perencanaan strategi dalam menambah kemampuan dan kinerja pegawai melalui kepuasan kerja dalam organisasi.

Kajian pustaka dalam penelitian ini memuat tentang pengertian dan indikator tiap-tiap variabel dari lingkungan kerja, kepuasan kerja, dan kinerja pegawai. Kinerja adalah cacatan outcome yang dihasilkan dari fungsi atau indikator suatu pekerjaan yang dicapai selama suatu periode waktu tertentu. Dimensi dan indikator yang digunakan dalam analisis penelitian ini mengacu pada pemikiran Wirawan (2009) yaitu: (1) kuantitas kerja dan kualitas kerja, dimana standar kuantitas dan kualitas kerja ditetapkan oleh organisasi, (2) sikap dan perilaku kerja pegawai, serta mampu beradaptasi dengan kondisi lingkungan kerjanya.

Lingkungan kerja adalah semua yang terdapat di sekitar tempat kerja pegawai yang dapat memengaruhi pegawai itu sendiri dalam menlaksanakan tugas dan tanggung jawab yang dibebankan baik yang berupa fisik ataupun non fisik dan secara langsung ataupun tidak langsung.kerja. Dimensi dan indikator yang dipakai dalam penelitian ini merujuk pada pendapat dari Sedarmayanti (2009) yang menyatakan bahwa dimensi lingkungan kerja terdiri dari dua yaitu (1) lingkungan kerja fisik, dan (2) lingkungan kerja non fisik. Adapun penjelasan mengenai dimensi yang digunakan untuk pengukuran lingkungan kerja adalah sebagai berikut: (1) lingkungan kerja fisik merupakan segala sesuatu yang terdapat di sekeliling tempat kerja, dan yang bisa memengaruhi pegawai baik secara langsung ataupun tidak langsung. Indikatornya yaitu pencahayaan, sirkulasi udara, suara bising, keamanan, ruang gerak, dan fasilitas kerja. (2) lingkungan kerja non fisik merupakan kondisi di tempat kerja yang berhubungan dengan ikatan baik rekan kerja dengan rekan kerja, dan anak buah ke atasan. Indikatornya yaitu hubungan pegawai.

Kepuasan kerja adalah perasaan atau perilaku umum seseorang atas situasi kerja disekitarnya dan apa yang diperoleh dari pekerjaan yang dilakukan. Dimensi dan indikator yang dipakai dalam penelitian ini merujuk pada buah pikiran Porter dalam Bagia (2005), yaitu (1) gaji dengan indikator gaji yang diterima oleh pegawai, upah yang sesuai, bonus yang diterima sesuai, dan bonus dapat meningkatkan pepuasan, (2) pekerjaan itu sendiri dengan indikator pekerjaan dan tugas sudah sesuai dengan keahlian, sesuai beban kerja, mampu menyelesaikan tugas, (3) promosi dengan indikator kesempatan untuk maju dan mendapat jabatan lebih tinggi, (4) Rekan kerja dengan indikator terjalin kerjasama dengan rekan kerja.

Hubungan antar variabel dalam penelitian ini dapat diungkapkan bahwa variabel dari lingkungan kerja dan kepuasan kerja berpengaruh terhadap kinerja pegawai, karena apabila kondisi lingkungan kerja nyaman dan kepuasan kerja tinggi maka kinerja pegawai akan meningkat dengan maksimal. Hal tersebut didukung dari teori yang diutarakan oleh Robbins (2003) dan Musriha (2011) yang mengatakan bahwa jika lingkungan kerja nyaman dan kepuasan kerja tinggi maka kinerja pegawai akan meningkat. Adanya pengaruh dari lingkungan kerja dan kepuasan kerja terhadap kinerja pegawai didukung oleh penelitian empirik dari Sulistiana dan Sarwoko (2014) yang menyimpulkan bahwa lingkungan kerja dan kepuasan kerja mempunyai penyaruh yang positif dan signifikan terhadap kinerja pegawai. Dengan demikian lingkungan kerja dan kepuasan kerja berpengaruh positif terhadap kinerja pegawai.

Lingkungan kerja berpengaruh terhadap kepuasan kerja pegawai, karena dengan lingkungan kerja yang aman dan nyaman akan meningkatkan rasa puas dan senang dalam 
bekerja. Menurut Anas (2013) menyatakan lingkungan kerja yang aman dan nyaman baik secara fisik ataupun nonfisik sangat diinginkan oleh pegawai agar dapat bekerja secara maksimal, namun sebaliknya apabila lingkungan sekitar kurang aman dan nyaman, maka kepuasan pegawai dalam bekerja tidak akan maksimal. Hal ini didukung oleh hasil kajian empirik dari Wibowo (2014) yang mengatakan bahwa lingkungan kerja berpengaruh positif dan signifikan terhadap kepuasan kerja. Dengan demikian lingkungan kerja memiliki pengaruh terhadap kepuasan kerja.

Lingkungan kerja yang sehat akan memberikan kondisi yang aman dan nyaman, dan menguatkan para pegawai agar dapat bekerja secara maksimum sehingga bisa meningkatkan kinerja pegawai. Pendapat dari Sopiah (2008) yang mengatakan bahwa lingkungan kerja dapat memengaruhi kinerja seseorang dalam bekerja. Hal ini didukung oleh kajian empirik dari Sofyan (2013) yang mengatakan bahwa lingkungan kerja mempunyai pengaruh positif dan signifikan terhadap kinerja pegawai. Oleh karena itu, kondisi dari lingkungan kerja sangat berpengaruh terhadap kinerja pegawai. Karena apabila kondisi lingkungan kerja aman, nyaman serta menyenangkan, pegawai akan menjalankan pekerjaan dan tanggung jawab yang dibebankan secara baik dan kinerja pegawai akan meningkat. Dengan demikian lingkungan kerja berpengaruh terhadap kinerja pegawai.

Kepuasan kerja adalah salah satu aspek penting dalam meningkatkan dan memaksimalkan kinerja pegawai. Menurut pendapat dari Mangkunegara (2005) yang mengatakan bahwa pegawai yang senang dengan pekerjaannya dapat lebih maksimal kinerjanya atau lebih produktif daripada yang kurang puas dan senang. Hal ini dipertegas oleh teori dari Sinambela (2012) yang mengatakan bahwa seseorang yang senang dan puas dengan tugas dan tanggung jawabnya akan terus memperbaiki kinerjanya. Oleh karena itu, kepuasan kerja yang tinggi dapat meningkatkan kinerja secara maksimal. Pendapat ini juga didukung oleh kajian empirik dari Wijaya (2018) yang mengatakan bahwa kepuasan kerja mempunyai pengaruh positif dan signifikan terhadap kinerja pegawai. Dengan demikian, kepuasan kerja berpengaruh terhadap kinerja pegawai.

\section{Metode}

Analisis ini dilakukan guna memeroleh gambaran tentang pengaruh dari lingkungan kerja dan kepuasan kerja terhadap kinerja pegawai pada Dinas Sosial Kabupaten Karangasem. Rancangan penelitian ini menggunakan jenis penelitian kuantitatif kausal yang dipakai untuk menguraikan hubungan sebab-akibat dari lingkungan kerja dan kepuasan kerja terhadap kinerja pegawai. Variabel penelitian yang digunakan dalam analisis ini ada tiga variabel, yaitu variabel bebas dalam penelitian ini adalah lingkungan kerja $\left(\mathrm{X}_{1}\right)$ dan kepuasan kerja $\left(\mathrm{X}_{2}\right)$, sedangkan yang menjadi variabel terikat dalam analisis ini adalah kinerja pegawai $(\mathrm{Y})$.

Subjek pada analisis ini adalah seluruh pegawai pada Dinas Sosial Kabupaten Karangasem. Sedangkan objek pada analisis penelitian ini adalah lingkungan kerja, kepuasan kerja, dan kinerja pegawai. Adapun populasi dalam analisis ini adalah seluruh pegawai pada Dinas Sosial Kabupaten Karangasem yang berjumlah 67 pegawai. Metode analisis data yang digunakan dalam penelitian ini yaitu analisis jalur (path analysis) yaitu analisis yang digunakan untuk menganalisis besarnya hubungan dan pengaruh langsung atau tidak langsung dari variabel lingkungan kerja $\left(\mathrm{X}_{1}\right)$, dan kepuasan kerja $\left(\mathrm{X}_{2}\right)$, terhadap kinerja pegawai $(Y)$ pada Dinas Sosial Kabupaten Karangasem. Untuk membantu proses pengolahan data secara cepat dan tepat maka digunakan program Statistical Package for Social Science (SPSS) 24.0 for Windows.

\section{Hasil dan Pembahasan}

Hasil analisis jalur dari pengaruh lingkungan kerja dan kepuasan kerja terhadap kinerja pegawai pada Dinas Sosial Kabupaten Karangasem tampak pada Tabel 1. 
Tabel 1. Hasil Analisis Jalur Pengaruh Lingkungan Kerja dan Kepuasan Kerja Terhadap Kinerja Pegawai

\begin{tabular}{lccc}
\hline Parameter & Koefisien & $p$-value & $A$ \\
\hline $\mathrm{Ryx}_{1} \mathrm{x}_{2}$ & 0,913 & 0,000 & 0,05 \\
$\mathrm{R}^{2} \mathrm{yx}_{1} \mathrm{x}_{2}$ & 0,833 & 0,000 & 0,05 \\
$\mathrm{Px}_{2} \mathrm{x}_{1}$ & 0,829 & 0,000 & 0,05 \\
$\mathrm{P}^{2} \mathrm{x}_{2} \mathrm{x}_{1}$ & 0,688 & 0,000 & 0,05 \\
$\mathrm{Pyx}_{1}$ & 0,445 & 0,000 & 0,05 \\
$\mathrm{P}^{2} \mathrm{yx}_{1}$ & 0,198 & 0,000 & 0,05 \\
$\mathrm{Pyx}_{2}$ & 0,509 & 0,000 & 0,05 \\
$\mathrm{P}^{2} \mathrm{yx}_{2}$ & 0,259 & 0,000 & 0,05 \\
$\mathrm{Px}_{2} \varepsilon_{1}$ & 0,312 & - & - \\
$\mathrm{Py}_{2}$ & 0,167 & - & - \\
\hline
\end{tabular}

Berdasarkan hasil uji analisis jalur pada Tabel 1, maka pengaruh dari masing-masing variabel lingkungan kerja dan kepuasan kerja terhadap kinerja pegawai pada Dinas Sosial Kabupaten Karangasem dapat dilihat pada Gambar 1.

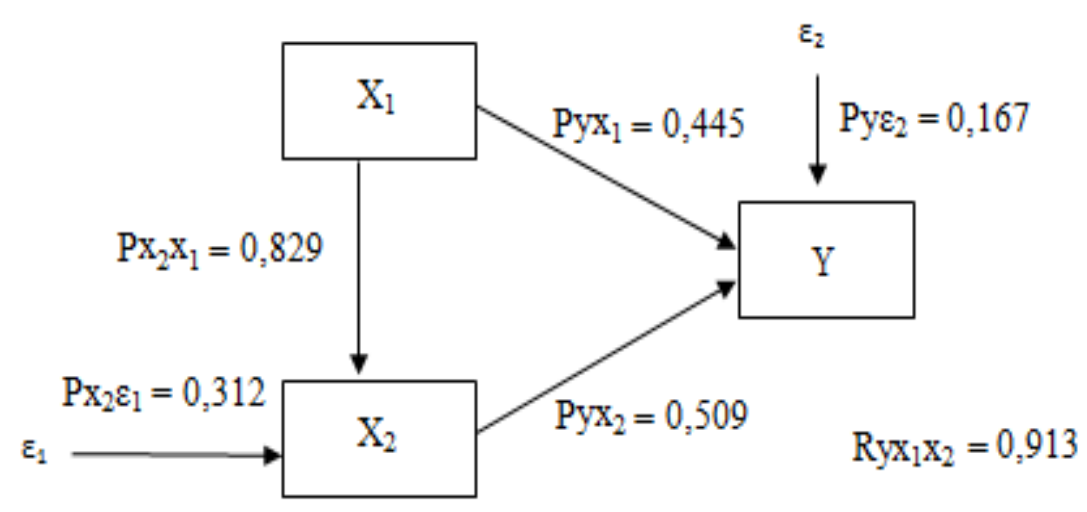

Gambar 1. Pengaruh $X_{1}$ dan $X_{2}$ terhadap $Y$ pada Dinas Sosial Kabupaten Karangasem

Besar sumbangan pengaruh langsung dan tidak langsung dari variabel lingkungan kerja dan kepuasan kerja terhadap kinerja pegawai dalam analisis ini dapat dilihat pada Tabel 2.

Tabel 2. Sumbangan Pengaruh Variabel Lingkungan Kerja dan Kepuasan Kerja Terhadap Kinerja Pegawai

\begin{tabular}{lcc}
\hline \multicolumn{1}{c}{ Keterangan } & Besar Sumbangan & Persentase \\
\hline Besar pengaruh langsung $\mathrm{X}_{1}$ terhadap $\mathrm{Y}$ & 0,198 & $19,8 \%$ \\
${\text { Besar pengaruh tidak langsung } \mathrm{X}_{1} \text { terhadap }}$ & 0,422 & $42,2 \%$ \\
$\mathrm{Y}_{\text {melalui }} \mathrm{X}_{2}$ & & \\
Besar pengaruh total $\mathrm{X}_{1}$ terhadap $\mathrm{Y}$ & 0,620 & $62,0 \%$ \\
Besar pengaruh total $\mathrm{X}_{1}$ terhadap $\mathrm{Y}$ & 0,620 & $62,0 \%$ \\
Besar pengaruh secara langsung $\mathrm{X}_{2}$ & 0,259 & $25,9 \%$ \\
terhadap $\mathrm{Y}$ & & \\
Besar pengaruh total $\mathrm{X}_{1}$ dan $\mathrm{X}_{2}$ terhadap $\mathrm{Y}$ & 0,879 & $87,9 \%$ \\
Besar pengaruh faktor lain terhadap $\mathrm{Y}$ & 0,121 & $12,1 \%$ \\
Total & 1,000 & $100,0 \%$ \\
\hline
\end{tabular}


Tabel 1 membuktikan bahwa lingkungan kerja $\left(X_{1}\right)$ dan kepuasan kerja $\left(X_{2}\right)$ berpengaruh positif dan signifikan terhadap kinerja pegawai $(Y)$ pada Dinas Sosial Kabupaten Karangasem. Besar sumbangan pengaruh secara keseluruhan lingkungan kerja $\left(X_{1}\right)$ dan kepuasan kerja $\left(X_{2}\right)$ terhadap kinerja pegawai $(Y)$ adalah 0,833 atau $83,3 \%$. Hasil analisis menunjukkan bahwa sebesar $83,3 \%$ kinerja pegawai $(Y)$ dipengaruhi oleh variabel lingkungan kerja $\left(X_{1}\right)$ dan kepuasan kerja $\left(X_{2}\right)$, sedangkan pengaruh lain sebesar 0,167 atau $16,7 \%$ dipengaruhi oleh variabel lain diluar dari variabel dalam penelitian ini. Hal tersebut mengindikasikan bahwa variabel lingkungan kerja $\left(\mathrm{X}_{1}\right)$ dan kepuasan kerja $\left(\mathrm{X}_{2}\right)$ berperan dalam upaya meningkatkan kinerja pegawai $(Y)$. Pengaruh lingkungan kerja $\left(X_{1}\right)$ terhadap kepuasan kerja $\left(X_{2}\right)$ sebesar 0,688. Hal tersebut menunjukkan bahwa sebesar $68,8 \%$ lingkungan kerja $\left(X_{1}\right)$ dipengaruhi oleh kepuasan kerja $\left(X_{2}\right)$, sedangkan pengaruh dari variabel lain sebesar $31,2 \%$. Pengaruh lingkungan kerja $\left(X_{1}\right)$ terhadap kinerja pegawai $(Y)$ sebesar 0,445 . Hal tersebut menunjukkan bahwa sebesar $44,5 \%$ lingkungan kerja $\left(X_{1}\right)$ dipengaruhi oleh kinerja pegawai $(Y)$ dan besar sumbangan pengaruhnya adalah 19,8\%. Pengaruh kepuasan kerja $\left(\mathrm{X}_{2}\right)$ terhadap kinerja pegawai $(Y)$ sebesar $50,9 \%$ dan besar sumbangan pengaruh dari kepuasan kerja $\left(X_{2}\right)$ terhadap kinerja pegawai $(Y)$ adalah $25,9 \%$.

Tabel 2 menunjukkan bahwa perbandingan pengaruh tidak langsung dari lingkungan kerja $\left(\mathrm{X}_{1}\right)$ terhadap kinerja pegawai $(\mathrm{Y})$ melalui kepuasan kerja $\left(\mathrm{X}_{2}\right)$ dengan pengaruh langsung lingkungan kerja $\left(X_{1}\right)$ terhadap kinerja pegawai $(Y)$ didapatkan hasil 42,2 \% > 19,8 $\%$, sehingga bisa dikatakan bahwa pengaruh dari lingkungan kerja $\left(X_{1}\right)$ secara tidak langsung terhadap kinerja pegawai $(Y)$ melalui kepuasan kerja $\left(\mathrm{X}_{2}\right)$ lebih besar pengaruhnya dari lingkungan kerja $\left(X_{1}\right)$ terhadap kinerja pegawai $(Y)$ pada Dinas Sosial Kabupaten Karangasem. Hasil penelitian ini didukung oleh hasil kajian empirik dari Sulistiana dan Sarwoko (2014) yang menyimpulkan bahwa lingkungan kerja dan kepuasan kerja mempunyai pengaruh positif dan signifikan terhadap kinerja pegawai.

Berdasarkan hasil analisis ditemukan bahwa secara tidak langsung pengaruh dari lingkungan kerja terhadap kinerja pegawai melalui kepuasan kerja pada Dinas Sosial Kabupaten Karangasem. Hasil penelitian menunjukan bahwa lingkungan kerja yang aman dan nyaman bisa meningkatkan kinerja pegawai melalui meningkatnya kepuasan kerja. Dengan begitu lingkungan kerja yang aman dan nyaman, dan kepuasan kerja yang tinggi bisa meningkatkan kinerja pegawai secara maksimal. Hasil analisis ini didukung hasil kajian empirik dari Sulistiana dan Sarwoko (2014) yang menyimpulkan bahwa lingkungan kerja dan kepuasan kerja berpengaruh signifikan terhadap kinerja pegawai.

Lingkungan kerja secara positif mempunyai pengaruh terhadap kepuasan kerja pegawai pada Dinas Sosial Kabupaten Karangasem. Hasil ini sejalan dengan yang dikemukakan oleh Anas (2013) yang mengatakan bahwa lingkungan kerja yang aman, baik, dan nyaman secara fisik maupun nonfisik sangat diinginkan oleh pegawai untuk bekerja secara maksimum, begitu juga sebaliknya jika lingkungan sekitar kurang nyaman, maka pegawai tidak akan merasa puasan dalam bekerja. Pimpinan organisasi perlu memerhatikan lingkungan kerja pegawai, karena dengan lingkungan kerja yang aman dan nyaman dapat mendorong semangat pegawai bekerja lebih dan pegawai akan merasa puas dengan apa yang ada disekitarnya serta pegawai akan betah berlama-lama di tempat kerja. Hasil analisis ini didukung hasil pengamatan dari Wibowo (2014) yang mengatakan bahwa lingkungan kerja mempunyai pengaruh positif dan signifikan terhadap kepuasan kerja.

Hasil analisis menunjukkan bahwa ada pengaruh lingkungan kerja terhadap kinerja pegawai. Temuan penelitian ini sejalan dengan pendapat Sopiah (2008) yang mengatakan bahwa lingkungan kerja dapat memengaruhi kinerja seseorang. Dengan lingkungan kerja yang nyaman, maka pegawai tersebut akan terdorong dan memiliki semangat dalam bekerja sehingga akan menghasilkan kinerja yang maksimal. Oleh karena itu kondisi lingkungan kerja yang nyaman dan menyenangkan, pegawai akan menyelesaikan tugas dan tanggung jawabnya yang diberikan secara efektif. Berdasarkan pengamatan dilapangan, pemberian lingkungan kerja pada Dinas Sosial Kabupaten Karangasem dikatakan kurang nyaman, dilihat dari kondisi ruang kerja yang kecil dan sempit, fasilitas kurang memadai, dan hubungan kerja dengan rekan kerja yang kurang harmonis menyebabkan pegawai kurang semangat untuk meningkatkan kinerjanya. 
Kepuasan kerja mempunyai pengaruh secara positif dan signifikan terhadap kinerja pegawai pada Dinas Sosial Kabupaten Karangasem. Hasil analisis ini sejalan dengan teori Mangkunegara (2005) yang mengatakan bahwa pegawai yang senang dan puas terhadap pekerjaannya dapat lebih baik kinerjanya atau lebih produktif daripada yang tidak puas. Dengan kepuasan kerja yang tinggi dapat mendorong semangat dan giat pegawai dalam bekerja. Oleh karena itu, organisasi harus memberikan kepuasan kepada pegawai dalam bekerja guna meningkatkan kinerja yang maksimal. Hal ini dipertegas oleh teori dari Sinambela (2012) yang mengatakan bahwa seseorang yang senang dan puas dalam pekerjaannya akan terus memperbaiki kinerjanya. Dengan kondisi lingkungan kerja yang aman dan nyaman dapat meningkatkan kinerja pegawai.

\section{Simpulan dan Saran}

Berdasarkan hasil analisis dan pembahasan, maka dapat ditarik beberapa simpulan sebagai berikut: (1) lingkungan kerja berpengaruh positif dan signifikan terhadap kinerja pegawai secara tidak langsung melalui kepuasan kerja. Hasil ini berarti lingkungan kerja berperan dalam meningkatkan kinerja pegawai secara tidak langsung melalui kepuasan kerja. (2) Lingkungan kerja berpengaruh positif dan signifikan terhadap kepuasan kerja. Hal ini berarti lingkungan kerja berperan dalam upaya meningkatkan kepuasan kerja pegawai. (3) Lingkungan kerja berpengaruh positif dan signifikan terhadap kinerja pegawai. Hal ini berarti lingkungan kerja berperan dalam upaya meningkatkan kinerja pegawai. (4) Kepuasan kerja berpengaruh positif dan signifikan terhadap kinerja pegawai. Hal ini berarti kepuasan kerja berperan dalam meningkatkan kinerja pegawai pada Dinas Sosial Kabupaten Karangasem.

Selanjutnya, dapat diajukan beberapa saran yaitu: (1) Bagi organisasi, diharapkan dapat lebih meningkatkan kinerja pegawainya melalui lingkungan kerja dan kepuasan kerja, karena penelitian ini membuktikan bahwa lingkungan kerja dan kepuasan kerja bisa memengaruhi kinerja pegawai. Adapun upaya yang bisa dilakukan untuk meningkatkan kinerja melalui lingkungan kerja, yaitu dengan memerhatikan lingkungan kerja yang ada di tempat kerja seperti penerangan yang sesuai, kesesuaian suhu/temperatur udara, suara bising dalam bekerja, keamanan di tempat kerja, ruang gerak yang mudah membuat pegawai leluasa dalam bergerak, fasilitas kerja yang lengkap dan memadai, dan hubungan yang harmonis dan terjalinnya kekeluargaan baik di tempat kerja maupun di luar kerja. Di samping lingkungan kerja, kepuasan kerja juga harus diperhatikan dengan cara memberikan besar gaji yang diterima oleh pegawai agar sesuai dengan Upah Minimun Kabupaten/Kota (UMK), memberikan bonus kepada pegawai yang melakukan pekerjaan lebih seperti lembur, atau pegawai yang paling sering datang tepat waktu sehingga dapat meningkatkan semangat pegawai dalam bekerja. Selain itu memberikan promosi jabatan juga bisa digunakan oleh organisasi guna meningkatkan kepuasan kerja sehingga kinerja pegawai meningkat, dengan memudahkan kesempatan pegawai untuk maju atau berprestasi dalam jenjang karir akan banyak pegawai bersemangat dan giat dalam bekerja, serta memberikan kesempatan pada pegawai untuk mengembangkan kemampuan dan keterampilan yang dimiliki pegawai, sehingga dapat memberikan ruang kreativitas pada pegawai untuk mendorong kinerja yang maksimal. Terjalinnya kerjasama yang harmonis antara sesama rekan kerja maupun ke atasan dalam menyelesaikan suatu pekerjaan, tugas dan tanggung jawab, dan adanya keterbukaan dalam berkomunikasi baik dengan atasan maupun dengan rekan kerja dapat memberikan rasa puas dalam diri pegawai sehingga kinerja akan terus meningkat. Karena kinerja pegawai yang baik akan mencerminkan baiknya kondisi kinerja Dinas Sosial Kabupaten Karangasem. Oleh karena itu, lingkungan kerja yang nyaman dan kepuasan kerja yang tinggi maka akan memengaruhi kinerja pegawai dalam mencapai target yang telah ditetapkan oleh organisasi. Namun, apabila lingkungan kerja kurang aman dan nyaman dan kepuasan kerja kurang maka dapat memengaruhi kinerja pegawai dalam mencapai target yang telah ditetapkan oleh organisasi. (2) Bagi peneliti selanjutnya yang tertarik untuk menganalisis aspek variabel yang sama mengenai lingkungan kerja, kepuasan kerja dan kinerja pegawai, dapat mengembangkan subjek penelitian yang lebih luas, dan juga dapat menguji variabel lain yang diduga kuat dapat memengaruhi kinerja pegawai. 
Karena dalam analisis ini hanya menggunakan dua variabel bebas, padahal masih banyak variabel lain yang dapat memengaruhi kinerja pegawai.

\section{Daftar Pustaka}

Anas, Khaidir. 2013. Pengaruh Kompensasi Dan Lingkungan Kerja Terhadap Kepuasan Kerja Karyawan PT. Karya Mitra Muda. Jurnal Manajemen ejournal.unp.ac, 2(1): 1-11

Bagia, I Wayan. 2015. Perilaku Organisasi. Yogyakarta: Graha IImu

Handoko, T. Hani. 2001. Manajemen Personalia dan Sumber Daya Manusia. Yogyakarta: BPFE

Mangkunegara, Anwar Prabu. 2005. Evaluasi Kinerja Sumber Daya Manusia. Bandung: Refika Aditama

Musriha. 2011. Influences Of Work Behavior, Work Environment and Motivation In Clove Cigarette Factories In Kudus, Indonesia. Academic Research International.Vol. 1, No.3, hlm.3

Robbins, Stephen P. 2003. Perilaku Organisasi. Jakarta: PT. Indeks Kelompok Gramedia

Robertson, Gordon. 2002. Revie Kinerja. BPKP dan Executive Education

Sedarmayanti.2009. Sumber Daya Manusia dan Produktivitas Kerja. Bandung: Penerbit Mandar Maju

Sinambela, Lijan Poltak. 2012. Kinerja Pegawai, Teori Pengukuran dan Implikasi. Yogyakarta: Graha IImu

Sofyan, Diana Khairani. 2013. Pengaruh Lingkungan Kerja Terhadao Kinerja Kerja Pegawai $B A P P E D A$. Industrial Engineering Journal.Vol.2 No.1, hlm. 18-23

Sopiah. 2008. Perilaku Organisasi. (Edisi 1). Yogyakarta: Penerbit Andi

Sukwiaty, Sudirman Jamal, dan Slamet Sukamto. 2007. Ekomoni. Surabaya: Yudhistira

Sulistiana, Siti., Endy Sarwoko. 2014. Pengaruh Lingkungan Kerja dan Kepuasan Kerja Terhadap Kinerja Karyawan PT. Mulia Jaya Muffler Malang.Journal Riset Mahasiswa Manajemen.Vol.2 No.1, hlm. 4

Sunyoto, Danang. 2012. Manajemen Sumber Daya Manusia. Jakarta: PT. Buku Seru

Wibowo, Mukti., Mochammad Al Musadieq, Gunawan Eko Nurtjanjono. 2014. Pengaruh Lingkungan Kerja Terhadap Kepuasan Kerja Karyawan (Study pada Karyawan PT. Telekomunikasi Indonesia Tbk. Kandatel Malang). Jurnal Administrasi Bisnis (JAB). Vol.16 No. 1, hlm. 4

Wijaya, Iwan Kurnia. 2018. Pengaruh Kepuasan Kerja Terhadap Kinerja Karyawan CV Bukit Sanomas. AGORA.Vol.6 No.2, hlm. 3

Wirawan. 2009. Evaluasi Kinerja Sumber Daya Manusia: Teori, Aplikasi, dan Penelitian. Jakarta: Salemba Empat 